\title{
Potential use of isosorbide dinitrate As a new drug for tilt table test of young adult subject: A study of haemodynamic effects
}

\author{
Yoga Yuniadi, Erika Maharani, Radityo Prakoso, Robert E Saragih, Muhammad Munawar
}

\begin{abstract}
Abstrak
Sinkop vasovagal merupakan masalah kesehatan yang sering didapatkan pada populasi dewasa muda. Tilt table test (TTT) merupakan satu-satunya metoda diagnosis sinkop vasovagal. Isoprenalin yang merupakan obat baku yang digunakan pada TTT saat ini sulit sekali didapatkan di Indonesia, oleh karena itu kami melakukan studi hemodinamik dari isosorbide dinitrate (ISDN) yang merupakan alternative bagi isoprenaline karena memiliki cara kerja yang serupa melalui penimbunan darah di vena. Sebanyak 17 orang dewasa muda yang sehat (rerata umur $28.6 \pm 4.7$ tahun, dan pria 14 orang) menjalani TTT dengan memakai ISDN $400 \mu \mathrm{g}$ disemprotkan sublingual sebagai obat provokatif. Perubahan hemodinamik yang terjadi selama fase dasar dan provokatif diukur. Tidak satupun dari 17 subyek yang mengalami sinkop. Sekalipun terdapat penurunan bermakna pada tekanan darah sistolik, diastolik dan tekanan rerata arteri serta peningkatan bermakana laju jantung, akan tetapi perubahan-perubahan itu tidak cukup bermakna untuk menyebabkan sinkop. Kesimpulannya pemberian ISDN semprot sublingual pada populasi dewasa muda sehat yang menjalani TTT menyebabkan perubahan hemodinamik yang bermakna tetapi tidak menimbulkan sinkop. Hasil penelitian ini dapat menjadi dasar bagi penggunaan ISDN sebagai obat provokatif pada TTT. (Med J Indones 2006; 15:24-9)
\end{abstract}

\begin{abstract}
Vasovagal syncope is a common health problem in young adult population. Tilt table test (TTT) is the only method to diagnose vasovagal syncope. Since isoprenaline as a standard provocative drug of TTT is hard to be found in Indonesia, we study the haemodynamic effect of isosorbide dinitrate (ISDN) which has similar venous pooling effect with isoprenaline. Seventeen young healthy adult subjects (age of $28.6 \pm 4.7$ year old, and 14 males) underwent TTT using $400 \mu \mathrm{g}$ ISDN spray sublingually as a provocative drug. The haemodynamic changes were observed during baseline and provocative phase. None of 17 subjects experienced of syncope. Although, the systolic, diastolic, and mean arterial blood pressure were significantly decreased and the heart rate significantly increased after ISDN administration, but the changes were not sufficient to cause syncopal event. In conclusion sublingual ISDN spray during TTT of young healthy adult subject changes haemodynamic measures but did not cause syncope. These results give a reasonable basic for ISDN usage as provocative drug of TTT. (Med J Indones 2006; 15:24-9)
\end{abstract}

Keywords: Syncope, vasovagal, tilt table test, nitrate

Syncope, which is a common medical problem, may be benign or may be the only warning before an episode causing sudden death. ${ }^{1}$ More than $40 \%$ of syncope patients in clinics were neurally mediated syncope. ${ }^{2}$ Neurocardiogenic (vasovagal) syncope is the most common of neurally mediated syncope, characterized by a sudden failure of the autonomic nervous system to maintain blood pressure and

Department of Cardiology and Vascular Medicine, Faculty of Medicine, University of Indonesia, and National Cardiovascular Center Harapan Kita, Jakarta, Indonesia sometimes heart rate at a level sufficient to maintain cerebral perfusion and consciousness. ${ }^{3}$

Tilt-table testing (TTT) is the only method for the diagnosis of neurocardiogenic syncope. ${ }^{4}$ Nowadays, isoprenaline is the standard drug to be used during TTT. ${ }^{5}$ However, isoprenaline is very difficult to be found in Indonesia, not only in remote area even in a big city like Jakarta. Isosorbide dinitrate (ISDN) is though to be an alternative to isoprenaline since it has the same venous pooling effect with small dose of isoprenaline. However, the results of ISDN administration during TTT are still contradictive. In the other hand, the haemodynamic effect of ISDN administration 
during TTT has not been elucidated widely, especially in normal young adult subject. Since ISDN is widely distributed in all over this country, it has a potential benefit to be used as a replacement drug for isoprenaline. We performed this study to give reasonable basic of ISDN usage for TTT purposes.

\section{METHODS}

Seventeen healthy young adult subjects (mean age of $28.6 \pm 4.7$ year old, male 14) without history of syncope were enrolled in this study. All respondents underwent physical examination and 12 lead ECG recording. Subjects with history of cardiovascular disease, consumed cardio-active drug, or having neurological problem were excluded. The eligible subjects underwent TTT during 4 hours fasting condition and intravenous line inserted. Continues ECG monitoring of biphasic defibrillator (Heartstart XL, Philips) and automatic digital sphygmomanometer (Dinamap Procare 100, General Electric) were used during TTT.

\section{TTT protocol}

The protocol of TTT has been published elsewhere. ${ }^{5}$ In brief, it consists of baseline and provocative phase. The subject lies down in supine position on tilting radiological table and tied up with soft band to keep the body on the table in occurrence of syncope. The baseline phase starts with supine pre-tilt phase lasting for 10 minutes. The heart rate and blood pressure were measured every 3 minutes. Then, the table was tilted of 70 degree for another 15 minutes and again the heart rate and blood pressure measurement were performed every 3 minutes. After completed the baseline phase, the test proceeded to the provocative phase. In provocative test, $400 \mu \mathrm{g}$ (2 puff) ISDN was sprayed sublingually during upright position and then underwent 20 minutes observation by measuring the blood pressure and heart rate every 3 minutes. The endpoint of TTT was episode of syncope or presyncope characterized by sudden abrupt of heart rate and/or blood pressure at anytime along the procedure. A cardiology resident and a nurse supervised the TTT procedure. (Figure 1)

\section{Definition}

Syncope was defined as a sudden and transient loss of consciousness and of postural tone with spontaneous recovery. ${ }^{6}$ Presyncope was defined as nearly syncope state.

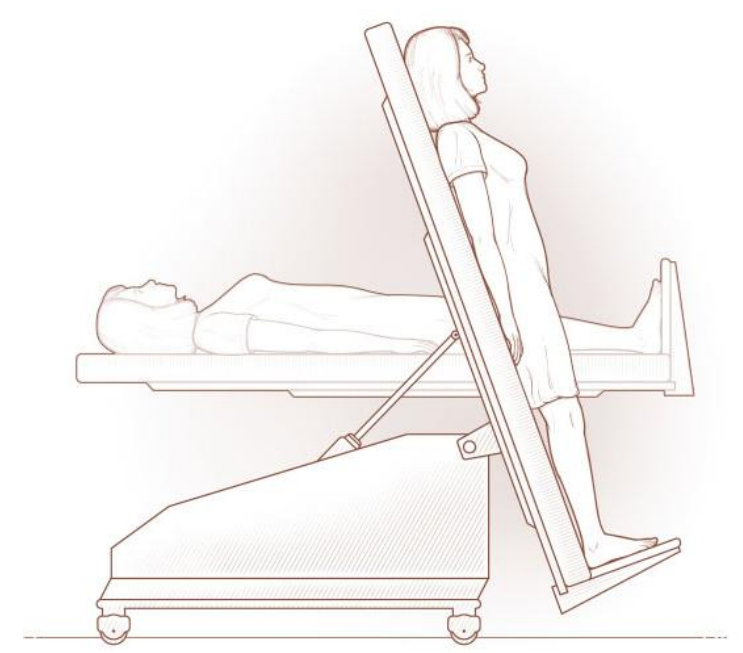

Figure 1. Illustration of tilt table test. The subject lies down on the tilting table, tied up with a soft band and then the table is tilted up to 70 degree. Heart rate and blood pressure are measured every 3 minutes.

ISDN spray that was used in this study comes from Mack (Isomack®).

Mean arterial pressure (MAP) was defined as the sum of systolic blood pressure with twice of diastolic blood pressure and then divided by 3 .

\section{Statistical analysis}

Statistical analysis was done using SPSS 11 program. Continues variable were presented as mean \pm SD. The differences between blood pressure and heart rate of baseline and provocative phase were tested by paired t-test. $\mathrm{P}$ value of $<0.05$ was considered statistically significant.

\section{RESULTS}

None of all 17 subject experienced syncope or presyncope during TTT. All measurements of systolic blood pressure during baseline were significantly different compare to that during provocative phase (Figure 2 and Table 1). These also true for diastolic blood pressure measurements, except for the first three minutes upright position. All sistolic blood pressure measurements decrease during provocative test, but the mean difference are only about $6-12 \mathrm{mmHg}$. No evidence of sudden abrupt of sistolic pressure to value 
of bellow $100 \mathrm{mmHg}$. A greater decline demonstrated in diastolic pressure measurements during provocative test as compare to that during baseline, which are about $4-16 \mathrm{mmHg}$. The mean arterial pressure (MAP) values along the test ranged from $75.7-95.8$
mmHg. The MAP of provocative phase 3 minutes after ISDN administration were significantly different compare to that during baseline tilted position $(\mathrm{p}<0.001$ for all time of measurements). The mean difference of MAP was about $12 \mathrm{mmHg}$. (Figure 3)

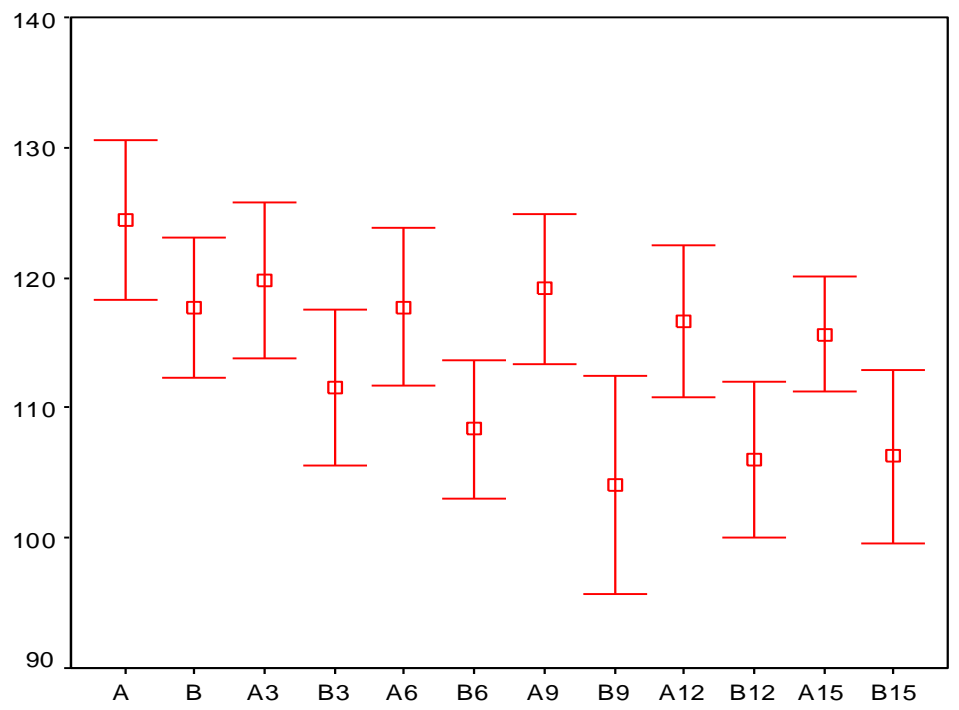

Figure 2. The diagram shows changes of systolic blood pressure (SBP) from tilting position of baseline phase (A) to provocative phase (B) with ISDN administration. A represents a mean measurement (heart rate) immediately after tilting position of baseline phase, A3 represents a mean measurement of 3 minutes after tilting of baseline phase, A6 is 6 minutes measurement of tilting baseline phase, etc. $B$ represents a mean measurement immediately after ISDN administration; B3 represents a mean measurement of 3 minutes after ISDN administration, etc. Bars limits represent $95 \%$ CI.

Table 1. Haemodynamic Measurements

\begin{tabular}{|c|c|c|c|c|c|c|c|c|c|c|c|c|}
\hline \multirow{2}{*}{ Time } & \multicolumn{4}{|c|}{ Baseline } & \multicolumn{4}{|c|}{ ISDN administration } & \multicolumn{4}{|c|}{$P$ value } \\
\hline & HR & SBP & DBP & MAP & HR & SBP & DBP & MAP & HR & SBP & DBP & MAP \\
\hline 0 & $78 \pm 9.7$ & $124 \pm 13$ & $81 \pm 10$ & $96 \pm 10$ & $86 \pm 9.3$ & $118 \pm 11$ & $78 \pm 10$ & $91 \pm 10$ & $<0.001$ & 0.019 & 0.089 & 0.024 \\
\hline 3 & $77 \pm 7.6$ & $120 \pm 12$ & $80 \pm 10$ & $93 \pm 10$ & $97 \pm 10$ & $112 \pm 12$ & $65 \pm 7$ & $81 \pm 7$ & $<0.001$ & 0.003 & $<0.001$ & $<0.001$ \\
\hline 6 & $78 \pm 9.4$ & $118 \pm 12$ & $80 \pm 7$ & $93 \pm 9$ & $98 \pm 12$ & $108 \pm 11$ & $66 \pm 8$ & $80 \pm 9$ & $<0.001$ & 0.001 & $<0.001$ & $<0.001$ \\
\hline 9 & $78 \pm 10$ & $119 \pm 12$ & $80 \pm 9$ & $93 \pm 10$ & $96 \pm 13.4$ & $104 \pm 17$ & $61 \pm 15$ & $76 \pm 15$ & $<0.001$ & 0.002 & $<0.001$ & $<0.001$ \\
\hline 12 & $78 \pm 8.1$ & $117 \pm 12$ & $78 \pm 7$ & $91 \pm 9$ & $91 \pm 16.9$ & $106 \pm 12$ & $65 \pm 11$ & $79 \pm 12$ & 0.001 & $<0.001$ & $<0.001$ & $<0.001$ \\
\hline 15 & $78 \pm 9.9$ & $116 \pm 9$ & $78 \pm 8$ & $90 \pm 8$ & $90 \pm 13.7$ & $106 \pm 14$ & $64 \pm 11$ & $78 \pm 11$ & $<0.001$ & 0.003 & $<0.001$ & $<0.001$ \\
\hline
\end{tabular}




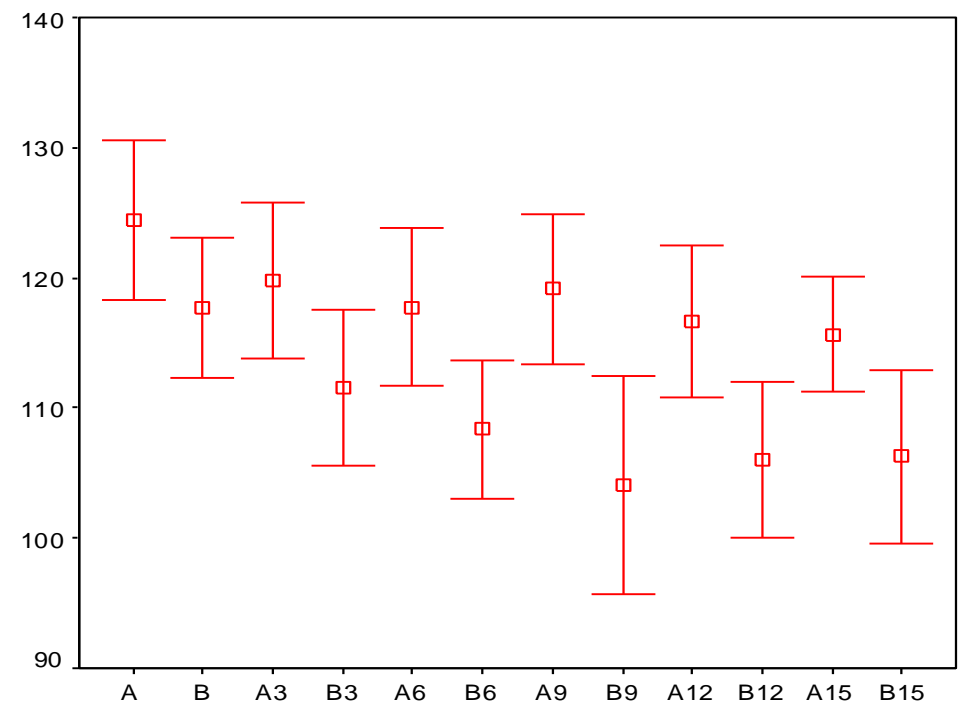

Figure 3. The diagram shows changes of mean arterial pressure (MAP) from tilting position of baseline phase (A) to provocative phase (B) with ISDN administration. All present legends have same meaning with that of figure 2.

The heart rate measurements during baseline were significantly different compare to that during provocative test. The heart rate increased during provocative test as compensation to the blood pressure reduction. No evidence of abrupt heart rate reduction to value of below $60 \mathrm{bpm}$, nor drastic heart rate increment.

\section{DISCUSSION}

This study showed that the usage of sublingual ISDN spray during TTT in healthy young adult subject change the haemodynamic parameters but did not provoke vasovagal syncope.

\section{Haemodynamic respons to TTT}

In healthy younger individuals with cerebral blood flow in the range of $50-60 \mathrm{ml} / 100 \mathrm{~g}$ tissue/min, that represents about 12 to $15 \%$ of resting cardiac output, are easily achieved. Those volume are correlated with minimum oxygen requirements necessary to sustain consciousness (approximately 3.0 to $3.5 \mathrm{ml} \mathrm{O} 2 / 100 \mathrm{~g}$ tissue/min). Cerebral perfusion pressure is largely dependent on systemic arterial pressure. Thus, any factor that decreases either cardiac output or total peripheral vascular resistance diminishes systemic arterial pressure and cerebral perfusion pressure. ${ }^{5}$ In regard to cardiac output, the most important physiological determinant is venous filling. Therefore, excessive pooling of blood in dependent parts of the body or diminished blood volume may predispose to syncope. Cardiac output may also be impaired due to bradyarrhythmias, tachyarrhythmias, or valvular disease.

The aim of tilting position during TTT is to enhance venous blood pooling. We used 70 tilting degree to prevent active extremities muscle contraction which could cause massage effect to the peripheral vein. At small dosage the most important action of nitrates is a pooling of blood in the large systemic venous capacitance vessels which leads to a decrease of central venous pressure and ventricular filling pressure. Only at higher dosage, is a distinct dilatation of systemic resistance vessels affected. Strohm et $\mathrm{al}^{7}$ studied the effect of nitrate (1.6 mg nitroglycerine) administration on diameter of abdominal vein of 26 healthy subjects. The result of ultrasound tomography measurements showed that nitroglycerine induced a relaxation of the abdominal veins. They suggest that the splanchnic veins participate essentially in the therapeutically important venous pooling effect of nitroglycerine. Vasovagal syncope usually occurs during orthostatic stress when not only is there pooling of something like 500-700 ml of blood in dependent vessels, but there is a progressive loss of a 
similar volume of plasma through dependent capillaries caused by the increased hydrostatic pressure. The overall effect of this stress is to reduce the rate of blood flow returning to the heart and consequently to reduce cardiac output.

Even though, the haemodynamic measures significantly change by nitrate administration, it was not sufficient to induce syncope. The MAP values were about 90.4 - $95.8 \mathrm{mmHg}$ during baseline phase, and $75.7-91.3$ $\mathrm{mmHg}$ during provocative phase. A severe hypotension (MAP $50 \mathrm{mmHg}$ ) is needed to produce significant hypoxemia. At this level the impulse traffic in the afferents from arterial baroreceptors is considerably reduced, and, consequently, tonic vasoconstrictor sympathetic discharge from the vasomotor center is disinhibited. ${ }^{8} \mathrm{~A}$ sudden cessation of cerebral blood flow for 6 to $8 \mathrm{~s}$ has been shown to be sufficient to cause complete loss of consciousness. ${ }^{5}$ Syncope was not occurred because the MAP was maintained above $50 \mathrm{mmHg}$ along the test. It was assumed that in healthy young adult subjects, administration of ISDN during TTT did not impair the integrity of crucial control mechanisms for maintaining adequate cerebral nutrient delivery, including: (a) cerebrovascular 'autoregulatory' capability, which permits cerebral blood flow to be maintained over a relatively wide range of perfusion pressures; (b) local metabolic and chemical control which permits cerebral vasodilatation to occur in the presence of either diminished $\mathrm{pO} 2$ or elevated $\mathrm{pCO} 2$; (c) arterial baroreceptor-induced adjustments of heart rate, cardiac contractility, and systemic vascular resistance, which modify systemic circulatory dynamics in order to protect cerebral flow; (d) and vascular volume regulation, in which renal and hormonal influences help to maintain central circulating volume. ${ }^{5}$

The systolic blood pressure decreased by nitrate administration, but in our study, its never reached value of $60 \mathrm{mmHg}$. Experience from tilt testing showed that a decrease in systolic blood pressure to $60 \mathrm{mmHg}$ is associated with syncope. ' Neurally mediated, or vasovagal, syncope is characterized by an abrupt fall in blood pressure resulting from widespread vasodilatation caused by a sudden cessation of sympathetic vasoconstrictor activity.

\section{Use of nitrate in TTT of young adult patients}

Since nitrate is easy to be found everywhere and cheap, it has been used as a provocative agent during
TTT recently. Kumar et $\mathrm{al}^{10}$ found that sublingual nitrate used during TTT of eldery patients increased false positive results even in asymptomatic patients. In addition, Ammirati et $\mathrm{al}^{11}$ administered $1.25 \mathrm{mg}$ ISDN at 30 minutes of TTT of unknown syncope patients (age of $40 \pm 22$ yo) and found that positive result increased from $19 \%$ to $58 \%$. However, to the best of our knowledge no study of haemodynamic effects of ISDN sublingual in healthy young adult persons underwent TTT was enrolled before. Yet, it is important to have such data because the majority vasovagal syncope are young adult population. Louis et $\mathrm{al}^{12}$, found that the prevalence of syncope in pediatrics of age less than 18 years old was $20 \%$. Lamb et $\mathrm{al}^{13}$ found that $26 \%$ of miltary population aged of $17-26$ yo experienced syncope. Then, it is worth to know the excact haemodynamic influence of nitrate administration to young healthy adult undergo TTT. In our study, administration of $400 \mu \mathrm{g}$ of ISDN sublingually resulted in significant haemodynamic changes but not significant enough to cause syncope or presyncope. Those results gave the preliminary basis of sublingual ISDN usage in TTT of young adult patients experienced with syncope.

\section{Limitation}

The majority of TTT study used pulse based tonometri to get realtime blood pressure measurement during the test. In this study we used digitally automatic sphyghmomanometer which measured the blood pressure every three minutes. Since the sphyghmomanometer need sufficient time to get measurement result in every measurement, then it is possible the results was not the realtime blood pressure during the event. But, as we did not observed any syncope or presyncope event in all subjects, the measurement results would be accurate.

\section{Conclusion}

In healthy young adult subject, sublingual ISDN spray during TTT decreases blood pressure but increases heart rate without symptom of syncope or presyncope. This result give a basis of potential usage of ISDN during TTT.

\section{REFERENCES}

1. Grubb BP. Neurocardiogenic syncope. $\mathrm{N}$ Engl J Med. 2005;352:1004-10. 
2. Mathias CJ, Deguchi K, Schatz I. Observations on recurrent syncope and presyncope in 641 patients. Lancet. 2001;357(9253):348-53.

3. Grubb BP, Karas B. Clinical disorders of the autonomic nervous system associated with orthostatic intolerance: an overview of classification, clinical evaluation, and management. Pacing Clin Electrophysiol. 1999;22(5):798-810.

4. Grubb BP, Kosinski D. Tilt table testing: concepts and limitations. Pacing Clin Electrophysiol. 1997;20(3 Pt 2):781-7.

5. Brignole M, Alboni P, Benditt D, Bergfeldt L, Blanc JJ, Bloch Thomsen PE, et al. Guidelines on management (diagnosis and treatment) of syncope. Eur Heart $\mathrm{J}$. 2001;22(15):1256-306.

6. Kapoor WN. Evaluation and management of the patient with syncope. JAMA. 1992;268(18):2553-60.

7. Strohm WD, Rahn R, Cordes HJ, Kurtz W, Kober G. Diameters of abdominal veins and arteries during nitrate therapy. Z Kardiol. 1983;72 Suppl 3:56-61.
8. Prakash ES, Madanmohan. When the heart is stopped for good: hypotension-bradycardia paradox revisited. Adv Physiol Educ. 2005;29:15-20.

9. Sheldon R, Killam S. Methodology of isoproterenol-tilt table testing in patients with syncope. J Am Coll Cardiol. 1992;19:773-9.

10. Kumar NP, Youde JH, Ruse CE. Responses to the prolonged head-up tilt followed by sublingual nitrate provocation in asymptomatic older adults. Age and Ageing. 2000;29:419-424

11. Ammirati F, Colivicchi F, Biffi A. Head-up tilt testing potentiated with low dose sublingual isosorbide dinitrate: a simplified time-saving approach for the evaluation of unexplained syncope. Am Heart J. 1998;135:671-676.

12. Lewis DA, Dhala A. Syncope in pediatric patient. Pediatr Clin North Am. 1999;46:205 - 19.

13. Lamb L, Green HC, Combs JJ, Cheesman SA, Hammond J. Incidence of loss of conciousness in 1980 Air Force personnel. Aerospace Med. 1960;12:973 - 88. 